\title{
Chemistry of gem-Dihalocyclopropanes. XV. Reactions of gem-Dihalocyclopropanes with Sodium Bis(2-methoxyethoxy)- aluminium Hydride, Lithium Aluminium Hydride, and
} Sodium Borohydride

\author{
LEIV KR. SYDNES AND LARS SKATTEBøL
}

Department of Chemistry, University of Oslo, Oslo 3, Norway

\begin{abstract}
Reactions of alkyl-substituted gem-dihalocyclopropanes, gem-dibromocyclopropyl alcohols, and alkyl gem-dibromocyclopropanecarboxylates with sodium bis(2-methoxyethoxy)aluminium hydride (SMEAH) yielded the corresponding monohalides in low to excellent yields. The monobromides were formed predominantly in the $E$ configuration. SMEAH reduction of 9,9 dihalobicyclo[6.1.0]nonane and 2,2-dibromo1-methylcyclopropylmethanol gave also significant amounts of the corresponding allenes. By the same reaction 1,1-dihalo-2,2,3,3-tetramethylcyclopropane gave 2-(1-methylcyclopropyl)propan-2-ol in low to moderate yield.

Reduction of gem-dibromocyclopropyl ketones with SMEAH, lithium aluminium hydride (LAH), and sodium borohydride yielded the corresponding alcohols in moderate to excellent yields. $g$ em-Dibromocyclopropyl alcohols were also formed by $\mathrm{LAH}$ reduction of some alkyl gem-dibromocyclopropanecarboxylates. In some cases small amounts of the corresponding (2E)-2-bromocyclopropylcarbinols were formed.

The mechanisms for the reductions are discussed.
\end{abstract}

Since the preparation of sodium bis(2-methoxyethoxy)aluminium hydride (SMEAH), $\mathrm{NaAl}\left(\mathrm{OCH}_{2} \mathrm{CH}_{2} \mathrm{OCH}_{3}\right)_{2} \mathrm{H}_{2}$, was described in $1968^{1,2}$ the chemical properties of this complex hydride have been extensively investigated. ${ }^{3-13}$ Generally its reducing power is similar to that of lithium aluminium hydride (LAH), but in some cases higher reactivity has been observed as in the case of organohalides which often are reduced more easily with SMEAH than with LAH. ${ }^{3,8}$ A preliminary report on the reduction of gem-dihalocyclopropane derivatives with SMEAH has been published ${ }^{14}$ and the present work represents a full account of that study.

The reductions were performed by dropwise addition of a benzene solution of the hydride to the gem-dihalocyclopropane derivative in the same solvent; finally the reaction mixture was quenched with hydrochloric acid. From initial experiments it was found that the yields of products depended on the amount of reducing agent and the reaction temperature but were hardly influenced by the reaction time. At $88{ }^{\circ} \mathrm{C}$ a $100 \%$ molar excess of SMEAH was used to ensure completion of the reaction. These conditions were used in most of the reductions described in this work.

A variety of substituted gem-dihalocyclopropyl derivatives were allowed to react with SMEAH. The corresponding monohalides were the main products, but variable amounts of fully dehalogenated compounds, including allenes, were also formed. The results are summarized in Table 1.

In most cases the monohalide was obtained as a mixture of the $E$ and $Z$ isomers in a ratio which was determined by ${ }^{1} \mathrm{H}$ NMR spectra or GLC analyses of the reaction mixture prior to distillation. The configurations of the isomeric monohalocyclopropanes were mostly determined by comparison of their IR and NMR spectra with those of authentic samples. Howover, in the case of the isomeric monobromides 13 the predominant isomer was assigned the $E$

Acta Chem. Scand. B 32 (1978) No. 9 
Table 1. Reaction of gem-dihalocyclopropane derivatives with sodium bis(2-methoxyethoxy)aluminium hydride (SMEAH).
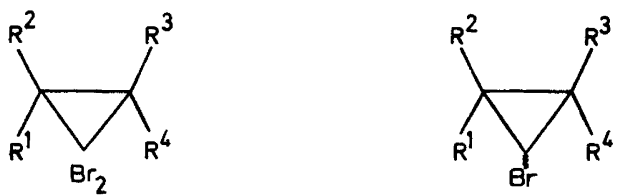

\begin{tabular}{|c|c|c|c|c|}
\hline Starting material & $\begin{array}{l}\text { Nota- } \\
\text { tion }\end{array}$ & $\begin{array}{l}\text { Yield } \\
(\%)^{a}\end{array}$ & $E / Z^{b}$ & Other products ( $\%$ yield $\left.{ }^{a}\right)$ \\
\hline $\begin{array}{l}\mathrm{X}=\mathrm{Br} ; \mathrm{R}^{1}=\mathrm{R}^{4}=\mathrm{H} ; \mathrm{R}^{2}, \mathrm{R}^{3}=\left(\mathrm{CH}_{2}\right)_{4}(1) \\
\mathrm{X}=\mathrm{Br} ; \mathrm{R}^{1}=\mathrm{R}^{4}=\mathrm{H} ; \mathrm{R}^{2}, \mathrm{R}^{3}=\mathrm{C}_{4} \mathrm{H}_{6}(4)^{c}\end{array}$ & $\begin{array}{r}2 \\
13\end{array}$ & $\begin{array}{l}60 \\
80\end{array}$ & $\begin{array}{l}75 / 25 \\
90 / 10\end{array}$ & $\begin{array}{l}\text { Bicyclo[4.1.0]heptane (3) }(25) \\
\text { Bicyclo[4.1.0]hept-2-ene }(22) \\
\text { (8) }\end{array}$ \\
\hline $\mathrm{X}=\mathrm{Cl} ; \mathrm{R}^{1}=\mathrm{R}^{4}=\mathrm{H} ; \mathrm{R}^{2}, \mathrm{R}^{3}=\left(\mathrm{CH}_{2}\right)_{6}(5)$ & 14 & 20 & $39 / 61$ & $\begin{array}{l}\text { Bicyclo[6.1.0]nonane }(23) \\
\text { 1,2-Cyclononadiene }(24)\end{array}$ \\
\hline $\begin{array}{l}\mathrm{X}=\mathrm{Br} ; \mathrm{R}^{1}=\mathrm{R}^{4}=\mathrm{H} ; \mathrm{R}^{2}, \mathrm{R}^{3}=\left(\mathrm{CH}_{2}\right)_{6}(6) \\
\mathrm{X}=\mathrm{C} ; \mathrm{R}^{1}=\mathrm{R}^{2}=\mathrm{R}^{4}=\mathrm{H} ; \mathrm{R}^{3}=\mathrm{Ph}(7) \\
\mathrm{X}=\mathrm{Br} ; \mathrm{R}^{1}=\mathrm{R}^{2}=\mathrm{R}^{4}=\mathrm{H} ; \mathrm{R}^{3}=\mathrm{Ph}(8) \\
\mathrm{X}=\mathrm{Br} ; \mathrm{R}^{1}=\mathrm{R}^{2}=\mathrm{H} ; \mathrm{R}^{3}=\mathrm{CH}_{2} \mathrm{OH} ; \mathrm{R}^{4}=\mathrm{CH}_{3}(9)\end{array}$ & $\begin{array}{l}15 \\
16 \\
17 \\
18\end{array}$ & $\begin{array}{l}43 \\
61 \\
51 \\
52\end{array}$ & $\begin{array}{l}80 / 20 \\
35 / 65 \\
79 / 21 \\
90 / 10\end{array}$ & $\begin{array}{l}23 \text { and } 24(27) \\
\text { Phenylcyclopropane (25) (30) } \\
25(45) \\
\text { 2-Methyl-2,3-butadien-1-ol }\end{array}$ \\
\hline $\begin{array}{l}\mathrm{X}=\mathrm{Br} ; \mathrm{R}^{1}=\mathrm{R}^{2}=\mathrm{H} ; \mathrm{R}^{3}=\mathrm{CH}_{2} \mathrm{OH} ; \mathrm{R}^{4}=\mathrm{Ph}(10) \\
\mathrm{X}=\mathrm{Br} ; \mathrm{R}^{1}=\mathrm{R}^{2}=\mathrm{H} ; \mathrm{R}^{3}=\mathrm{CO}_{2} \mathrm{Et} ; \mathrm{R}^{4}=\mathrm{CH}_{3}(11) \\
\mathrm{X}=\mathrm{Br} ; \mathrm{R}^{1}=\mathrm{R}^{4}=\mathrm{CH}_{3} ; \mathrm{R}^{2}=\mathrm{H} ; \mathrm{R}^{3}=\mathrm{CO}_{2} \mathrm{Et}(12)\end{array}$ & $\begin{array}{l}19 \\
20 \\
21\end{array}$ & $\begin{array}{l}15 \\
63 \\
48^{\circ}\end{array}$ & $\begin{array}{l}d \\
70 / 30 \\
65 / 35\end{array}$ & $\begin{array}{l}(E) \text {-2,2-Dibromo-1,3-dimeth- } \\
\text { ylcyclopropylmethanol }(27) \\
(12)^{c}\end{array}$ \\
\hline
\end{tabular}

a Yield of isolated product. ${ }^{b}$ In an $E$ isomer the halogen atom and $R^{3}$ are trans to each other. ${ }^{c} 7,7-$ Dibromobicyclo[4.1.0] hept-2-ene. ${ }^{d}$ The product consisted of a single isomer. ${ }^{e}$ Calculated yield (see text).

configuration on the basis of spectral data and lack of reactivity towards silver nitrate in ethanol. ${ }^{15}$ The configuration of 2 -bromo-1phenylcyclopropylmethanol (19) which is isomerically homogeneous is not certain.

In addition to the gem-dihalocyclopropanes included in Table 1, 1,1-dichloro-2,2,3,3-tetramethylcyclopropane (28) and 1,1-dibromo2,2,3,3-tetramethylcyclopropane (29) were also treated with SMEAH. Both yielded mixtures of 2-(1-methylcyclopropyl)propan-2-ol (30) and the corresponding monohalide in ratios depending on the halogen atoms present as well as the amount of SMEAH employed.

When 2-acetyl-1,1-dibromo-2-methylcyclopropane (31) reacted with SMEAH the carbonyl group was preferentially reduced resulting in an $80 \%$ yield of 1-(2,2-dibromo-1-methylcyclopropyl)ethanol (32). According to GLC analysis this alcohol consisted of a 4:1 mixture of diastereomers; the predominant isomer was identical with the single product obtained from reductions of 31 with LAH or sodium borohydride (SBH) (vide infra). A small amount of 1 .
[(E)-2-bromo-1-methylcyclopropyl]ethanol (33) was also isolated.

Similar results were obtained when $(E)$-2. acetyl-1,1-dibromo-2,3-dimethylcyclopropane (34) was allowed to react with SMEAH; 1-[(E)2,2-dibromo-1,3-dimethylcyclopropyl]ethanol (35) and 1-[(2E,3E)-2-bromo-1,3-dimethylcyclopropyl]ethanol (36) were formed in 70 and $5 \%$ yields, respectively. GLC revealed that alcohol 35 was a 4:1 mixture of diastereomers.

In contrast to ester 11 which is reduced exclusively to the corresponding monobromo ester 20 (Table 1), ethyl (E)-2,2-dibromo-1,3dimethylcyclopropanecarboxylate (12) yielded a 4:1 mixture of ethyl (3E)-2-bromo-1,3-dimethylcyclopropanecarboxylate $(21)$ and $(E)-2,2$ dibromo-1,3-dimethylcyclopropylmethanol (27) when treated with SMEAH. The products were isolated as a mixture in $60 \%$ total yield.

The results summarized in Table 1 clearly show that the monobromides are preferably formed in the $E$ configuration. The same stereoselectivity is observed in reductions of similar compounds with sodium methylsulfinyl car-

Acta Chem. Scand. B 32 (1978) No. 9 
banion ${ }^{16}$ and $O, O^{\prime}$-diethyl $\alpha$-lithiomethylphosphonate ${ }^{17}$ which almost certainly involve $\alpha$ bromocyclopropyl carbanions as intermediates. This suggests that the SMEAH reduction of gem-dibromocyclopropyl derivatives takes place via cyclopropyl carbanions as well and evidence for this assumption was obtained from several experiments. Both 9,9-dibromobicyclo[6.1.0]nonane $(6)$ and 2,2-dibromo-1-methylcyclopropylmethanol (9) reacted with SMEAH to give substantial amounts of 1,2-cyclononadiene (24) and 2-methyl-2,3-butadien-1-ol (26), respectively (Table 1); these allenes are the main products from treatment of 6 and 9 with methyllithium, ${ }^{18-20}$ reactions which certainly involve carbanion type intermediates. ${ }^{21}$ Further support was obtained from reactions of 1,1dibromo-2,2,3,3-tetramethylcyclopropane (29) with SMEAH which gave 2-(1-methylcyclopropyl)propan-2-ol (30) as one of the products; the formation of this alcohol is best rationalized as outlined in Scheme 1.19,22

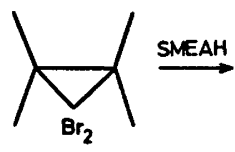

29

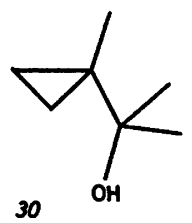

Scheme 1.

We suggest a cyclic intermediate for the carbanion-forming step as depicted in Fig. 1. Clearly, transition state $a$ is sterically preferred and should lead predominantly to the $E$ isomer provided that protonation of the resulting anion occurs prior to inversion.

On the other hand, the stereochemistry of the monochlorides from reactions of gem-dichlorocyclopropanes with SMEAH (Table 1) is similar to that observed with tributyltin hydride ${ }^{23}$ which certainly reduces gem-dihalocyclopropanes via cyclopropyl radicals. ${ }^{23,24}$ However, formation of small amounts of 1,2.

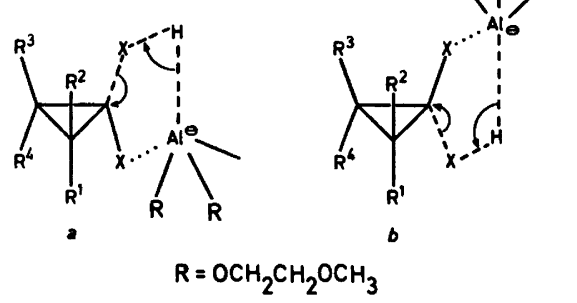

Fig. $1 . \mathrm{R}^{2}, \mathrm{R}^{3}$ is more bulky than $\mathrm{R}^{1}, \mathrm{R}^{4}$.

cyclononadiene from dichloride 5 (Table 1) and alcohol 30 from 1,1-dichloro-2,2,3,3-tetramethylcyclopropane strongly indicates a carbanion mechanism also for these SMEAH reductions. The predominant formation of the $Z$ isomer may be due to a higher rate of inversion for $\alpha$-chlorocyclopropyl anions than for the bromo analogues. ${ }^{25}$

In addition to the corresponding monohalides SMEAH reduction of some gem-dihalocyclopropanes yielded substantial amounts of the corresponding hydrocarbons (Table 1) which could partly be monodeuterated by quenching the reaction mixtures with $\mathrm{D}_{2} \mathrm{O}$-DCl instead of $\mathrm{H}_{2} \mathrm{O}-\mathrm{HCl}$; thus, 1,1-dibromo-2-phenylcyclopropane gave phenylcyclopropane which contained $60 \%$ 1-phenylcyclopropane-2- $d_{1}$. This indicates that the hydrocarbon formation takes place via cyclopropyl anions which can be formed either by substitution on carbenoid carbons by hydride ions ${ }^{28}$ (path a, Scheme 2) or by reaction of monohalocyclopropanes with SMEAH (path b, Scheme 2).

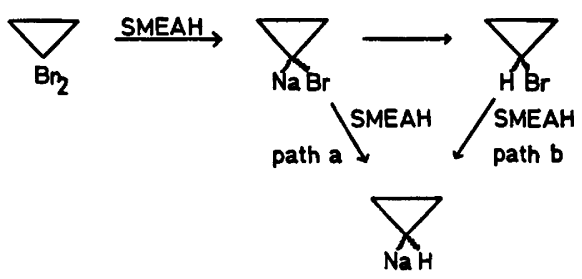

Scheme 2.

For comparison some gem-dibromocyclopropyl ketones and esters were treated with LAH and SBH. When ketones 31 and 34, 2-acetyl1,1-dibromo-2,3,3-trimethylcyclopropane (37), and 1,1-dibromo-2-isobutyryl-2,3,3-trimethyl- 
Table 2. Reactions of gem-dibromocyclopropyl ketones and ethyl 2,2-dibromocyclopropanecarboxylates with lithium aluminium hydride (LAH) under nitrogen and sodium borohydride (SBH) under an atmosphere of air.

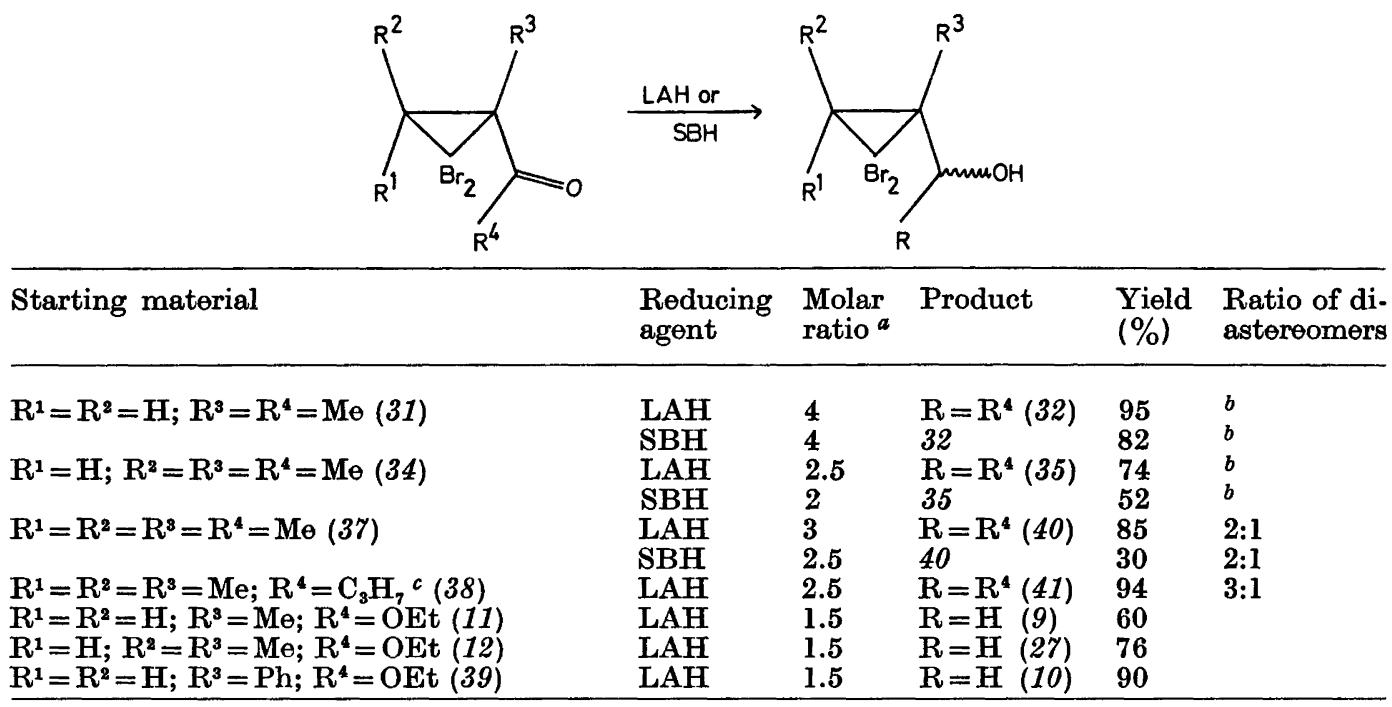

${ }^{a}$ Molar ratio $=\mathrm{mol}$ of gem-dibromocyclopropane derivative: mol of reducing agent. ${ }^{b}$ One diastereomer. ${ }^{c} \mathrm{C}_{3} \mathrm{H}_{7}=$ isobutyl.

cyclopropane (38) reacted with either LAH in ether under nitrogen or SBH in ethanol under an atmosphere of air, regioselective reductions took place resulting in formation of the corresponding gem-dibromocyclopropyl alcohols in moderate to excellent yields (Table 2); hence the regioselectivity of these reactions is the same as when SMEAH is employed. Generally the yields were appreciably higher with LAH than with SBH, but with the former small amounts of the corresponding monobromocyclopropyl alcohols were formed from 31 and 34. These minor products consisted of single isomers which were shown to have $E$ configura. tion by comparison with authentic samples.

Hydride reduction of the carbonyl group of the ketones studied can produce mixtures of diastereomeric alcohols which indeed occurred in LAH and SBH reductions of the ketones 37 and 38 (Table 2) and when 31 and 34 were treated with SMEAH. On the other hand, reduction of 31 and 34 with LAH and SBH afforded single isomers of the alcohols 32 and 35 (Table 2); however, their configurations cannot be established from the spectral data available and the high degree of stereoselectivity remains unexplained.

Acta Chem. Scand. B 32 (1978) No. 9
The regioselectivity of the LAH reductions of gem-dibromocyclopropyl esters was opposite to that observed with SMEAH; the esters 11 and 12 as well as ethyl 2,2-dibromo-1-phenylcyclopropanecarboxylate (39) gave the corresponding 2,2-dibromocyclopropylmethanol derivatives in variable yields (Table 2). In two cases (esters 11 and 39) some of the monobromocyclopropylmethanol was also formed; 2-bromo-1-methylcyclopropylmethanol (18) was isolated in a $20 \%$ yield while alcohol 10 was admixed with a small amount of 2-bromo1-phenylcyclopropylmethanol (19). These minor products were both single isomers; in the former case the bromine atom and the hydroxymethyl substituent were situated $E$ to each other whereas the stereochemistry of 19 remains uncertain.

The esters were recovered unchanged after reaction with an ethanol solution of SBH under an atmosphere of air.

The formation of (2E)-2-bromocyclopropylcarbinols in some of the reductions carried out with LAH deserves some comment. Since monobromocyclopropyl ketones or esters were not observed in any of the reactions, these alcohols are most likely formed by reductive dehalogena- 


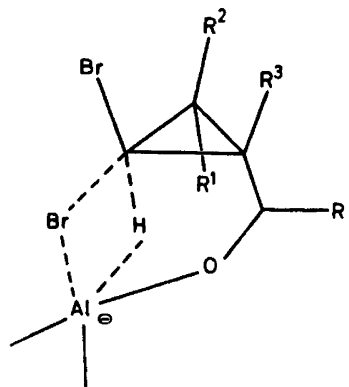

Fig. 2.

tion of initially formed gem-dibromocyclopropyl alcohols. The dehalogenation can be explained by a four-centre mechanism: ${ }^{27}$ the bromine atom $Z$ to the oxygen function is attacked intramolecularly by alkoxyaluminium hydride as depicted in Fig. 2. If this were correct, treatment of 2,2-dibromo-1-methylcyclopropylmethanol with LAH would give carbinol $18 E$ which turned out to be the case, albeit in low yield (10\%). The same mechanism also explains the stereoselective formation of the monobromocyclopropyl alcohols 33 and 36 from SMEAH reduction of ketones 31 and 34, respectively.

\section{EXPERIMENTAL}

General. The apparatus employed have been described elsewhere. ${ }^{28}$ Elemental analyses were carried out by Ilse Beetz Microanalytical Laboratory, 8640 Kronach, West Germany.

Starting materials. Most of the gem-dihalocyclopropyl derivatives used were prepared as described in the literature. ${ }^{19,29-32}$ Alcohols 9 and 10 were obtained by LAH reduction of esters 11 and 39 (Table 2).

Reduction of gem-dihalocyclopropanes with sodium bis(2-methoxyethoxy)aluminium hydride (SMEAH); general procedure. SMEAH, usually $100 \%$ molar excess, was added as a $70 \%$ solution in benzene * to a vigorously stirred solution of gem-dihalocyclopropane $(2-4 \mathrm{ml}$ of benzene $/ 0.01 \mathrm{~mol}$ of cyclopropane) in benzene kept at $88^{\circ} \mathrm{C}$. The white reaction mixture was stirred at bath temperature for $2-5 \mathrm{~h}$ and then hydrolyzed with $10 \%$ hydrochloric acid. The products were extracted with benzene and ether; the combined organic fraction was washed with water and dried $\left(\mathrm{MgSO}_{4}\right)$. Evaporation of solvent left a colourless residue which was analyzed by GLC prior to distillation.

\footnotetext{
* Commercially available from Aldrich as such.
}

The following compounds were treated with SMEAH according to this procedure.

7,7-Dibromobicyclo[4.1.0]heptane (1) gave 7bromobicyclo[4.1.0]heptane (2), b.p. 64-67 ${ }^{\circ} \mathrm{C} / 13 \mathrm{mmHg}$ (lit. ${ }^{23}$ b.p. $96-99{ }^{\circ} \mathrm{C} / 36 \mathrm{mmHg}$ ) and bicyclo[4.1.0]heptane (3), b.p. $114-117^{\circ} \mathrm{C}$ (lit. ${ }^{33}$ b.p. $116-117^{\circ} \mathrm{C}$ ). The isomeric composition of 2 was determined by GLC (20\% SE30, $130^{\circ} \mathrm{C}$ ) and ${ }^{1} \mathrm{H}$ NMR. ${ }^{23}$

7,7-Dibromobicyclo[4.1.0]hept-2-ene (4) afforded bicyclo[4.1.0]hept-2-ene (22), b.p. 53$54^{\circ} \mathrm{C} / 95 \mathrm{mmHg}$ (lit. ${ }^{34}$ b.p. $115^{\circ} \mathrm{C}$ ) and an isomeric mixture of 7-bromocyclo[4.1.0] hept-2-ene (13), b.p. $92-94^{\circ} \mathrm{C} / 30 \mathrm{mmHg}$. Anal. $\mathrm{C}_{7} \mathrm{H}_{9} \mathrm{Br}$ : C, H. ${ }^{1} \mathrm{H}$ NMR $\left(60 \mathrm{MHz}, \mathrm{CCl}_{4}\right): \delta 1.10-2.45$ $(6 \mathrm{H}, \mathrm{m}), 2.78$ and $3.33(1 \mathrm{H}, 2 \mathrm{t}$ in a ratio of $9: 1$, $J 3$ and $7.5 \mathrm{~Hz}), 5.18-6.15(2 \mathrm{H}, \mathrm{m})$. IR $\left(\mathrm{CCl}_{4}\right)$ : $3020(\mathrm{~s}), 1630(\mathrm{~m}), 1055(\mathrm{~m}), 1040(\mathrm{~m}), 1033(\mathrm{~s})$, $925(\mathrm{~m}), 858(\mathrm{~s}), 650(\mathrm{~s}) \mathrm{cm}^{-1}$. The isomeric composition was confirmed by GLC $(20 \%$ SE30, $\left.125^{\circ} \mathrm{C}\right)$.

9,9-Dichlorobicyclo[6.1.0]nonane (5) was transformed to a mixture of 9-chlorobicyclo[6.1.0]nonane (14), b.p. $80-82{ }^{\circ} \mathrm{C} / 5 \mathrm{mmHg}$ (lit. ${ }^{35}$ b.p. $77-79^{\circ} \mathrm{C} / 8 \mathrm{mmHg}$ ), bicyclo[6.1.0]nonane (23), ${ }^{31}$ and 1,2-cyclononadiene $(24) .^{19}$ The isomeric composition of 14 was determined by GLC (20\% SE30, $\left.160^{\circ} \mathrm{C}\right)$.

9,9-Dibromobicyclo[6.1.0]nonane (6) afforded a mixture of 9-bromobicyclo[6.1.0] nonane (15), b.p. $44-46{ }^{\circ} \mathrm{C} / 0.18 \mathrm{mmHg}$ (lit. ${ }^{23}$ b.p. $40-42$ ${ }^{\circ} \mathrm{C} / 0.13 \mathrm{mmHg}$ ) and hydrocarbons 23 and 24 which boiled as a mixture at $52-56{ }^{\circ} \mathrm{C} / 12$ $\mathrm{mmHg}$. The isomeric ratio of 15 and the composition of the mixture of 23 and 24 were determined by GLC $\left(20 \% \mathrm{SE30}, 115-170^{\circ} \mathrm{C}\right)$.

1,1-Dichloro-2-phenylcyclopropane (7) gave 1-chloro-2-phenylcyclopropane (16) as a mixture of stereoisomers, b.p. $66-70^{\circ} \mathrm{C} / 4 \mathrm{mmHg}$ (lit. ${ }^{36}$ b.p. $68-73^{\circ} \mathrm{C} / 4 \mathrm{mmHg}$ ), and phenylcyclopropane (25), b.p. 88-91 ${ }^{\circ} \mathrm{C} / 51 \mathrm{mmHg}$ (lit. ${ }^{37}$ b.p. $\left.90-91{ }^{\circ} \mathrm{C} / 52 \mathrm{mmHg}\right)$. GLC (20\% SE30, $170^{\circ} \mathrm{C}$ ) revealed the isomeric composition of 16 .

1,1-Dibromo-2-phenylcyclopropane (8) was converted to a mixture of 25 and 1-bromo-2phenylcyclopropane (17), b.p. $53-55^{\circ} \mathrm{C} / 0.20$ mmHg (lit. ${ }^{23}$ b.p. $48-50{ }^{\circ} \mathrm{C} / 0.15 \mathrm{mmHg}$ ). The isomeric composition was determined by GLC $\left(20 \% \mathrm{SE30}, 175^{\circ} \mathrm{C}\right)$.

When 8 reacted with a $400 \%$ molar excess of SMEAH and the reaction mixture was quenched with $\mathrm{D}_{2} \mathrm{O}-\mathrm{DCl}$ a $60 \%$ yield of phenylcyclopropane containing $60 \%$ l-phenylcyclopropane-2- $d_{1}$ was obtained. The spectral data were in accordance with those published. ${ }^{38}$

2,2-Dibromo-1-methylcyclopropylmethanol (9) afforded a 65:35 mixture of 2-bromo-1-methylcyclopropylmethanol $(18)^{39}$ and 2 -methyl-2,3butadien-1-ol $(26)^{20}$ according to IR, NMR, and GLC $\left(20 \%\right.$ SE30, $\left.98{ }^{\circ} \mathrm{C}\right)$. The products were isolated as a mixture in $80 \%$ total yield, b.p. $92-94^{\circ} \mathrm{C} / 16 \mathrm{mmHg}$. According to ${ }^{1} \mathrm{H}$ NMR 18 was a 9:1 mixture of the $E$ and $Z$ isomers.

2,2-Dibromo-1-phenylcyclopropylmethanol (10) 
was transformed to a complex mixture of soveral products of which only 2-bromo-1phenylcyclopropylmethanol (19), isolated as an impure oil in $15 \%$ yield, was identified. ${ }^{1} \mathrm{H}$ NMR (60 $\left.\mathrm{MHz}, \mathrm{CCl}_{4}\right): \delta 1.08-1.59(2 \mathrm{H}$, $\mathrm{m}$ ), 2.45 (1 H, broad s), 3.07 (1 H, AB-q, $J 5$ and $8 \mathrm{~Hz}), 3.40(2 \mathrm{H}$, broad $\mathrm{s}), 7.10-7.35$ (5 H, m). IR (film): 3600 (s), 1110 (s), 1030 (m), $700(\mathrm{~m}) \mathrm{cm}^{-1}$.

Ethyl 2,2-dibromo-1-methylcyclopropanecarboxylate (11) gave a $63 \%$ yield of a stereoisomeric mixture of ethyl 2-bromo-1-methylcyclopropanecarboxylate (20), b.p. $44-46^{\circ} \mathrm{C} /$ $0.80 \mathrm{mmHg}$ (lit. ${ }^{40}$ b.p. $31^{\circ} \mathrm{C} / 0.08 \mathrm{mmHg}$ ). The isomeric ratio was determined by ${ }^{1} \mathrm{H} \mathrm{NMR}^{39}$ and GLC (10\% PEG 4000, $\left.150^{\circ} \mathrm{C}\right)$.

Ethyl (E)-2,2-dibromo-1,3-dimethylcyclopropanecarboxylate (12) was converted to a mixture of ethyl (3E)-2-bromo-1,3-dimethylcyclopropanecarboxylate $(21)^{39}(58 \%),(3 E)-2,2$-dibromo-1,3-dimethylcyclopropylmethanol $(14 \%)$, and unreacted $12(28 \%)$. A mixture of 21 and 27 was isolated in $60 \%$ total yield, b.p. $50-56^{\circ} \mathrm{C} / 0.60 \mathrm{mmHg}$. The isomeric ratio of 21 was determined by ${ }^{1} \mathrm{H}$ NMR and GLC (10\% QF1, $160^{\circ} \mathrm{C}$ ).

A pure sample of 27 was obtained by preparative GLC (same conditions). Anal. $\mathrm{C}_{8} \mathrm{H}_{10} \mathrm{Br}_{2} \mathrm{O}$ : C, H. ${ }^{1} \mathrm{H}$ NMR (60 MHz, CCl $): \delta 1.20-1.70$ (1 $\mathrm{H}, \mathrm{m}), 1.17$ (3 H, d, J 5.5 Hz), $1.25(3 \mathrm{H}, \mathrm{s})$, 3.13 (1 H, s), 3.65 (1 H, d, J $12 \mathrm{~Hz}$ ), 3.73 (1 H, d, J $12 \mathrm{~Hz}$ ). Ir (film): 3380 (m), 1040 (s), 995 (m), $768(\mathrm{~m}), 750(\mathrm{~m}) \mathrm{cm}^{-1}$.

1,1-Dichloro-2,2,3,3-tetramethylcyclopropane (28) gave a mixture of 1-chloro-2,2,3,3-tetramethylcyclopropane, b.p. $70-72^{\circ} \mathrm{C} / 100 \mathrm{mmHg}$ (lit. ${ }^{41}$ b.p. $72^{\circ} \mathrm{C} / 105 \mathrm{mmHg}$ ), and 2-(1-methylcyclopropyl)propan-2-ol (30). The latter compound was identified by comparison with an authentic sample. ${ }^{22}$ The yield of the monochloride varied from 45 to $30 \%$ while that of 30 was 1 to $5 \%$.

1,1-Dibromo-2,2,3,3-tetramethylcyclopropane (29) afforded a mixture of 1-bromo-2,2,3,3-tetramethylcyclopropane, b.p. $54-55^{\circ} \mathrm{C} / 23 \mathrm{mmHg}$ (lit. ${ }^{23}$ b.p. $51{ }^{\circ} \mathrm{C} / 22 \mathrm{mmHg}$ ), and alcohol 30 , m.p. $35-37^{\circ} \mathrm{C}$ (lit. ${ }^{22}$ m.p. $39^{\circ} \mathrm{C}$ ). The yields varied with the amount of SMEAH employed, for the monobromide from 30 to $5 \%$ and for alcohol 30 from 2 to $30 \%$.

2-Acetyl-1,1-dibromo-2-methylcyclopropane (31) gave 1-(2,2-dibromo-1-methylcyclopropyl)ethanol (32), b.p. $52-54{ }^{\circ} \mathrm{C} / 0.15 \mathrm{mmHg}$ (lit. ${ }^{42}$ b.p. $\left.51-52^{\circ} \mathrm{C} / 0.1 \mathrm{mmHg}\right)$. GLC (15\% dinonyl phthalate, $145^{\circ} \mathrm{C}$ ) revealed the presence of two diastereomers in a ratio of $4: 1$. In addition 1[(E)-2-bromo-1-methylcyclopropyl]ethanol (33) was isolated in $10 \%$ yield, b.p. $38{ }^{\circ} \mathrm{C} / 0.70$ mmHg (lit. ${ }^{38}$ b.p. $39-41^{\circ} \mathrm{C} / 0.80 \mathrm{mmHg}$ ).

(E)-2-Acetyl-1,1-dibromo-2,3-dimethylcyclopropane (34) afforded 1-[(E)-2,2-dibromo1,3-dimethylcyclopropyl] ethanol (35), b.p. 52 ${ }^{\circ} \mathrm{C} / 0.10 \mathrm{mmHg}$. Anal. $\mathrm{C}_{7} \mathrm{H}_{12} \mathrm{Br}_{2} \mathrm{O}: \mathrm{C}, \mathrm{H} .{ }^{1} \mathrm{H}$ NMR $\left(60 \mathrm{MHz}, \mathrm{CCl}_{4}\right): \delta 0.97-1.40(10 \mathrm{H}, \mathrm{m}), 2.23$ (1 H, s), 3.66 (1 H, q, J 6.5 Hz). IR (film): 3300 (m), 1035 (m), 945 (m), 905 (s), 800 (m), 750 (s) $\mathrm{cm}^{-1}$. According to GLC (10\% PEG 4000, $140^{\circ} \mathrm{C}$ ) the distilled product was a $4: 1$ mixture of diastereomers. In addition an impure sample of 1-[(2E,3E)-2-bromo-1,3-dimethylcyclopropyl]ethanol (36) was isolated, b.p. $45-48^{\circ} \mathrm{C} /$ $0.35 \mathrm{mmHg}$ (lit. ${ }^{39}$ b.p. $48-49^{\circ} \mathrm{C} / 0.35 \mathrm{mmHg}$ ).

Treatment of 7-bromobicyclo[4.1.0]hex-2-ene (13) with silver nitrate. A solution of an isomeric mixture of 13 in ethanol was treated with ethanolic silver nitrate at room temperature. A white precipitate formed immediately. GLC $\left(20 \% \mathrm{SE} 30,130{ }^{\circ} \mathrm{C}\right)$ revealed that the minor isomer had been consumed while the predominant isomer was unreactive.

Reduction with lithium aluminium hydride (LAH); general procedure. The reactions were carried out under pure nitrogen. An excess of LAH was added in portions to a cooled (ice/ water) solution of ketone or ester in dry ether (3 $\mathrm{ml} / \mathrm{mmol}$ substrate). The reaction mixture was stirred at room temperature for $4 \mathrm{~h}$ and then hydrolyzed with $2 \mathrm{M} \mathrm{HCl}$. The product was extracted with ether and dried $\left(\mathrm{MgSO}_{4}\right)$. Evaporation of the solvent left a pale yellow residue which was worked up by distillation or crystallization.

Reduction with sodium borohydride ( $S B H$ ) under an atmosphere of air; general procedure. A suspension of an excess of SBH in ethanol (3 $\mathrm{ml} / \mathrm{mmol}$ of hydride) was added in portions to a cooled (ice/water) solution of ketone or ester in ethanol ( $2 \mathrm{ml} / \mathrm{mmol}$ of substrate). The reaction mixture was stirred at room temperature for $4 \mathrm{~h}$, then quenched with $0.5 \mathrm{M} \mathrm{HCl}$ and extracted with ether; the combined extracts were dried $\left(\mathrm{MgSO}_{4}\right)$. The products were worked up as described above.

In addition to alcohols 27,32 and 35 the following compounds were prepared according to one or both of these procedures.

1-(2,2-Dibromo-1,3,3-trimethylcyclopropyl)ethanol (40), b.p. $72{ }^{\circ} \mathrm{C} / 0.13 \mathrm{mmHg}$. Anal. $\mathrm{C}_{8} \mathrm{H}_{14} \mathrm{Br}_{2} \mathrm{O}: \mathrm{C}, \mathrm{H}$. ${ }^{1} \mathrm{H}$ NMR $\left(60 \mathrm{MHz}, \mathrm{CCl}_{4}\right)$ : $\delta 1.06-1.52(9 \mathrm{H}$, partly overlapping singlets), 2.00 ( $1 \mathrm{H}$, broad s), 3.95 and 4.02 ( $1 \mathrm{H}, 2 \mathrm{q}$ in a ratio of $1: 2$, respectively, $J 6.5 \mathrm{~Hz}$ for both). IR (film): 3400 (s), 1054 (s), 1036 (s), 1003 (w), 990 (w), 938 (s), $900(\mathrm{~m}), 795$ (s) $\mathrm{cm}^{-1}$.

1-(2,2-Dibromo-1,3,3-trimethylcyclopropyl)-2methylpropan-1-ol (41), b.p. $75^{\circ} \mathrm{C} / 0.08 \mathrm{mmHg}$. Anal. $\mathrm{C}_{10} \mathrm{H}_{18} \mathrm{Br}_{2} \mathrm{O}: \mathrm{C}, \mathrm{H}$. ${ }^{1} \mathrm{H}$ NMR (60 MHz, $\left.\mathrm{CCl}_{4}\right): \delta 0.65-1.66(16 \mathrm{H}$, complex mixture of singlets, doublets, and multiplets), 1.83 ( $1 \mathrm{H}$, $\mathrm{s}), 3.25$ and 3.35 ( $1 \mathrm{H}, 2 \mathrm{~d}$ in a ratio of $3: 1$, respectively, $J 9 \mathrm{~Hz}$ for both). IR (film): 3575 (m), $3480(\mathrm{~m}), 1020(\mathrm{~s}), 950(\mathrm{~m}), 788(\mathrm{~s}) \mathrm{cm}^{-1}$.

2,2-Dibromo-1-methylcyclopropylmethanol (9), b.p. $64^{\circ} \mathrm{C} / 0.97 \mathrm{mmHg}, \mathrm{m} . p .67^{\circ} \mathrm{C}$ from pentane (lit. ${ }^{42}$ b.p. $60-61{ }^{\circ} \mathrm{C} / 0.9 \mathrm{mmHg}$, m.p. $66.5^{\circ} \mathrm{C}$ from pentane). In addition $(E)$-2-bromo-1methylcyclopropylmethanol $(18 E)$ was isolated in $20 \%$ yield. ${ }^{39}$

2,2-Dibromo-1-phenylcyclopropylmethanol (10), m.p. $52.5{ }^{\circ} \mathrm{C}$ from hexane. Anal. $\mathrm{C}_{10} \mathrm{H}_{10} \mathrm{Br}_{2} \mathrm{O}$ :

Acta Chem. Scand. B 32 (1978) No. 9 
C, H. ${ }^{1} \mathrm{H}$ NMR (60 MHz, $\left.\mathrm{CCl}_{4}\right): \delta 1.98(3 \mathrm{H}, 2$ broad s), 3.72 ( $1 \mathrm{H}, \mathrm{d}, J 11.5 \mathrm{~Hz}$ ), 3.90 (1 H, d, $J 11.5 \mathrm{~Hz}), 7.27$ (5 H, broad s). IR $\left(\mathrm{CCl}_{4}\right)$ : 3610 (s), 1105 (s), 1050 (s), 1030 (shoulder), $1010(\mathrm{~m}), 690(\mathrm{~s}) \mathrm{cm}^{-1}$. In addition alcohol 19 was isolated as an impure liquid in $4 \%$ yield. This product consisted of the same isomer that was formed when alcohol 10 was treated with SMEAH.

Treatment of 2,2-dibromo-1-methylcyclopropylmethanol (9) with $L A H$. LAH (2.5 mmol) was added in portions to a cooled (ice/water) solution of $9(4.7 \mathrm{mmol})$ in dry ether $(10 \mathrm{ml})$. The reaction mixture was stirred at room-temperature for $12 \mathrm{~h}$ and then worked up in the usual way. Evaporation of the ether left a pale yellow residue which contained a 1:7 mixture of $(E)$-2bromo-1-methylcyclopropylmethanol $(18 E)$ and 9 as well as a compound the structure of which has not been elucidated.

\section{REFERENCES}

1. Vit, J., Casensky, B. and Machacek, J. French Pat. 1,515,582 (1968).

2. Casensky, B., Machacek, J. and Abraham, K. Collect. Czech. Chem. Commun. 36 (1971) 2648.

3. Bazant, V., Capka, M., Cerny, M., Chvalovsky, V., Kochloef, K., Kraus, M. and Malek, J. Tetrahedron Lett. (1968) 3303.

4. Corbett, J. F. Chem. Commun. (1968) 1257.

5. Capka, M., Chvalovsky, V. and Kraus, M. Collect. Czech. Chem. Commun. 34 (1969) 118.

6. Cerny, M., Malek, J., Capka, M. and Chvalovsky, V. Collect. Czech. Chem. Commun. 34 (1969) 1025, p. 1033.

7. Kraus, M. and Kochloefl, K. Collect. Czech. Chem. Commun. 34 (1969) 1823.

8. Capka, M. and Chvalovsky, V. Collect. Czech. Chem. Commun. 34 (1969) 2782.

9. Capka, M. and Chvalovsky, V. Collect. Czech. Chem. Commun. 34 (1969) 3110.

10. Cerny, M. and Malek, J. Tetrahedron Lett. (1969) 1739.

11. a. Cerny, M. and Malek, J. Collect. Czech. Chem. Commun. 35 (1970) 1216, pp. 2030, 3079; b. Ibid. 36 (1971) 2394.

12. Jones, T. K. and Peet, J. H. J. Chem. Ind. London (1971) 995.

13. Zobacova, A., Hermankova, V. and Jary, J. Collect. Czech. Chem. Commun. 42 (1977) 2540.

14. Sydnes, L. and Skattebøl, L. Tetrahedron Lett. (1974) 3703.

15. Ghosez, L., Laroche, P. and Slinckx, G. Tetrahedron Lett. (1967) 2767.

16. Osborn, C. L., Shields, T. C., Shoulders, B. A., Cardenas, C. G. and Gardner, P. D. Chem. Ind. London (1965) 766.

17. Oshima, K., Shirafuji, T., Yamamoto, H. and Nozaki, H. Bull. Chem. Soc. Jpn 46 (1973) 1233.
18. Skattebøl, L. Tetrahedron Lett. (1961) 167.

19. Skattebøl, L. Acta Chem. Scand. 17 (1963) 1683.

20. Nilsen, N. O., Sydnes, L. K. and Skattebøl, L. Chem. Commun. (1978) 128.

21. Köbrich, G. Angew. Chem. 79 (1967) 15.

22. Skattebøl, L. Tetrahedron Lett. (1970) 2361.

23. Seyferth, D., Yamazaki, H. and Alleston, D. L. J. Org. Chem. 28 (1963) 703.

24. Kuivila, H. G. Acc. Chem. Res. 1 (1968) 299.

25. Walborsky, H. M. and Motes, J. M. J. Am. Chem. Soc. 92 (1970) 2445, and references therein.

26. Kitatani, K., Yamamoto, H., Hiyama, T. and Nozaki, H. Bull. Chem. Soc. Jpn 50 (1977) 2158.

27. Yamanaka, H., Yagi, T., Teramura, K. and Ando, T. Chem. Commun. (1971) 380.

28. Kleveland, K. and Skattebøl, L. Acta Chem. Scand. B 29 (1975) 827.

29. Makosza, $M$. and Wawrzyniewicz, $M$. Tetrahedron Lett. (1969) 4659.

30. Huang, Y.-I., Hsing, I.-T. and Tai, H.-I. Hua Hsueh Hsueh Pao 30 (1964) 306; Chem. Abstr. 61 (1964) $13211 \mathrm{f}$.

31. Schuster, D. I. and Le日, F.-T. Tetrahedron Lett. (1965) 4119.

32. Sydnes, L. K. Acta Chem. Scand. B 31 (1977) 823.

33. Smith, R. D. and Simmons, H. E. Org. Synth. 41 (1961) 72.

34. Wittig, G. and Wingler, F. Chem. Ber. 97 (1964) 2146.

35. Ando, T., Hosaka, H., Yamanaka, H. and Funasaka, W. Bull. Chem. Soc. Jpn. 42 (1969) 2013.

36. Hausser, J. W. and Pinkowski, N. J. J. Am. Chem. Soc. 89 (1967) 6981.

37. Bumgardner, C. L. J. Am. Chem. Soc. 83 (1961) 4420.

38. Berson, J. A., Pedersen, L. D. and Carpenter, B. K. J. Am. Chem. Soc. 98 (1976) 122.

39. Sydnes, L. K. Acta Chem. Scand. B 32 (1978) 47.

40. Sydnes, L. K., Skattebøl, L., Chapleo, C. B., Leppard, D. G., Svanholt, K. L. and Dreiding, A. S. Helv. Chim. Acta 58 (1975) 2061.

41. Closs, G. L. and Closs, L. E. J. Am. Chem. Soc. 81 (1959) 4996.

42. Kleveland, K., Skattebøl, L. and Sydnes, L. K. Acta Chem. Scand. B 31 (1977) 463 .

Received April 28, 1978. 